INFO ARTIKEL

Riwayat Artikel

Diterima : :01 Januari 2020

Disetujui : 26 Februari 2020

\title{
PENDIDIKAN
}

\section{STUDI KEMAMPUAN BERFIKIR SPASIAL SISWA KELAS $X$ PADA MATA PELAJARAN GEOGRAFI DI SMA NEGERI 2 MUARA PINANG}

\author{
Levinda Sari ${ }^{1}$, Siti Asiyah ${ }^{2}$, Murjainah $^{3}$, Dessy Wardiah ${ }^{4}$
}

1 SMA Negeri 2 Muara Pinang, Empat Lawang

${ }^{2-3}$ Pendidikan Geografi, Universitas PGRI Palembang

4 Pendidikan Bahasa dan Sastra Indonesia, Universitas PGRI Palembang

(区) levindasari330@gmail.com ${ }^{1}$, asiyahgeoadventure@gmail.com ${ }^{2}$

\begin{abstract}
ABSTRAK
Tujuan dari penelitian ini adalah untuk mengetahui kemampuan spasial siswa kelas X SMA Negeri 2 Muara Pinang, Sumatera Selatan. Meode yang digunakan adalah metode penelitian deskriptif. Sumber data dalam penelitian ini adalah siswa SMA Negeri 2 Muara Pinang. Teknik pengumpulan data yang digunakan adalah observasi, koesioner, dan dokumentasi. Teknik analisis data dilakukan secara persentase. Berdasarkan koesioner yang telah dibagikan kepada siswa kelas X SMA Negeri 2 Muara Pinang dapat menunjukkan bahwa kemampuan spasial siswa cukup baik, meskipun masih ada siswa merespon belum sesuai fakta. Hal ini dapat terlihat dari kemampuan siswa dalam menjawab soal tentang kemampuan untuk mengenali jarak, pola spasial sekolah, menganalisis fenomena alam, kemampuan mengetahui kondisi sekolah. Penelitian ini perlu dilakukan lebih lanjut agar dapat diketahui sejauh mana pengaruhnya terhadap siswa.
\end{abstract}

Kata kunci : kemampuan berfikir spasial, Geografi, siswa

\section{PENDAHULUAN}

Setiap warga negara Indonesia merupakan individu yang berhak mendapatkan pendidikan dari tingkat dasar hingga tingkat menengah. Pemerintah memiliki kewajiban dalam memberikan pendidikan yang layak bagi warganya dalam hal ini sudah dijamin dalam undang-undang yang tertuang dalam sistem pendidikan nasional. Sistem Pendidikan nasional pada hakikatnya merupakan pencerminan dari upaya sadar sebuah bangsa untuk membangun keberlanjutan warisan budaya dan jati diri sebagai bangsa berdaulat dan bermartabat (Musanna, 2017).

Mewujudkan suatu bangsa yang berdaulat dan bermartabat melalui pendidikan, peserta didik ditanamkan nilai-nilai karakter dan pengetahuan melalui proses pembelajaran di sekolah dengan berbagai mata pelajaran. Salah satunya adalah mata pelajaran geografi. Geografi adalah ilmu tentang persamaan dan perbedaan fenomena geosfer dengan sudut pandang kewilayahan dan kelingkungan dalam konteks keruangan. Sejak manusia lahir di dunia, manusia sangat bergantung pada alam lingkungannya. Manusia membutuhkan alam untuk dapat memenuhi kebutuhan hidupnya. Inilah awal lahirnya studi geografi (NN, Murjainah, \& Tobari, 2018).

Menurut Bonawati dalam NN, Murjainah, \& Tobari (2018) mengungkapkan Geografi merupakan ilmu yang sama-sama mempelajari bumi. Karakteristik geografi sebagai ilmu nampak dari sasaran kajiannya yang khas disebut sebagai 
objek material dan objek formal. Selain itu, siswa dimotivasi secara aktif untuk menelaah bahwa kebudayaan dan pengalaman mempengaruhi persepsi manusia tentang tempat-tempat dan wilayah. Dengan demikian siswa diharapkan bangga akan warisan budaya dengan memiliki kepedulian kepada keadilan sosial, proses-proses demokratis dan kelestarian ekologis, yang pada gilirannya dapat mendorong siswa untuk meningkatkan kualitas kehidupan di lingkungannya pada masa kini dan masa depan.

Lebih lanjut, Sumaatmadja dalam Okta, Murjainah, \& Edi (2019) mendeskripsikan pembelajaran geografi hakikatnya adalah pembelajaran tentang aspek-aspek keruangan permukaan bumi yang merupakan keseluruhan gejala alam dan kehidupan umat manusia dengan variansi kewilayahan. Pembelajaran geografi di sekolah merupakan pembelajaran yang meliputi aspek-aspek kelingkungan, dan kewilayahan dengan objek studi geografi adalah geosfer yang terdiri atas atmosfer, litosfer, hidrosfer dan biosfer yang disesuaikan dengan tingkat perkembangan psikologi siswa pada jenjang-jenjang Pendidikan.

Berdasarkan Permendikbud Nomor 24 Tahun 2016 tentang Kompetensi Inti dan Kompetensi Dasar Pelajaran pada Kurikulum 2013 pada Pendidikan Dasar dan Pendidikan Menengah ditetapkan mata pelajaran Geografi (Lampiran 50) untuk kelas X, XI, dan XII, mempunyai KD pengetahuan dan KD keterampilan sesuai dengan pokok bahasan mata pelajaran, seperti disajikan pada tabel 1, tabel 2, dan tabel 3 terlampir. Berdasarkan KD pengetahuan, KD keterampilan dan pokok bahasan pelajaran Geografi tersebut, maka standar kompetensi (SKL) siswa adalah mempunyai kemampuan spasial Geografi (Nofirman, 2018).

Karenanya, pembelajaran geografi dalam keterkaitan kewilayahan dalam konteks keruangan bertujuan untuk memberikan pengetahuan dan pemahaman siswa terhadap kemampuan spasial. Kemampuan spasial menurut Hanafi (2016) berawal dari kecerdasan seseorang mempunyai kemampuan memandang dan menanggapi berbagai hal. Bahkan dengan kecerdasan seseorang dapat mengantisipasi hal-hal yang akan terjadi, seperti bencana alam, penentuan lokasi yang ideal untuk bermukim, dan lain-lain. Sementara itu, pemikiran spasial adalah keterampilan dasar yang bisa diakses oleh semua orang ke derajat yang berbeda dalam konteks yang berbeda untuk menyelesaikan masalah dalam berbagai konteks (Hidayat, dkk dalam Rahayu, Murjainah, \& Idris, 2019). Sementara itu, Oktavianto, Sumarmi, \& Handoyo, (2017) mendefinisikan pemikiran spasial sebagai kemampuan yang dapat digunakan oleh seorang ahli geografi untuk menganalisis hubungan spasial di bumi. Kemampuan ini akan sangat berguna bagi siswa ketika memutuskan atau membuat keputusan dari hal-hal yang sangat sederhana hingga komplikasi yang berkaitan dengan ruang atau lokasi. Ketika seseorang bepergian, dia harus tahu tentang jarak dan arah, sehingga dia bisa memprediksi waktu kedatangan dan tidak tersesat.

Bila diperhatikan pada implementasi kurikulum 2013 yang penerapannya dengan pendekatan saintifik, SMA Negeri 2 Muara Pinang khususnya guru mata pelajaran geografi dalam pelaksanaannya terdapat kendala yang dihadapi, seperti ketidakcukupan waktu sehingga proses kegiatan belajar mengajar yang berlangsung menjadi kurang efektif, guru mengalami kesulitan karena terbatasnya penggunaan komputer laptop dan LCD yang ada di sekolah. Padahal konsep dari geografi masih abtrak, terutama pemahaman siswa terhadap wilayah maupun keruangan. Kemudian, hasil observasi yang telah dilakukan terdapat beberapa siswa yang belum memahami tentang fenomena alam terutama materi mengenai kewilayahan dan ruang, masih banyak siswa yang kurang mengerti atau tidak mengetahui fenomena alam yang ada di sekolah. Ini berimplikasi pada pemahaman siswa dalam memahami daerah tempat tinggal dan sekitarnya.

Hasil penelitian Rahayu, Murjainah, \& Idris (2019) mengenai The Effect of Google Earth Utilization on Students' Spatial Thinking Ability menunjukkan bahwa terdapat perbedaan dalam kemampuan berpikir spasial siswa kelompok eksperimen yang diperlakukan menggunakan Google Earth selama proses pembelajaran dengan kelas kontrol yang tidak menggunakan Google Earth dimana hasil belajar geografi kelas eksperimen lebih tinggi dibandingkan dengan kelas control. Hasil penelitian tersebut menunjukkan 
pentingnya kemampuan spasial bagi siswa dalam belajar terutama dalam meningkatan hasil belajar siswa. Sementara itu, hasil penelitian Nofirman (2018) tentang studi kemampuan spasial siswa kelas XII di SMA 6 Kota Bengkulu menunjukkan bahwa kemampuan spasial siswa berada pada kelompok cukup mempunyai jumlah terbanyak, (43,55\%). Penguasaan kemampuan spasial geografi siswa ditemukan pada kelompok cukup yang mempunyai jumlah terbanyak (38.71\%). Berdasarkan hal tersebut, maka tujuan dalam penelitian ini adalah untuk mengetahui kemampuan spasial siswa kelas X SMA Negeri 2 Muara Pinang Kabupaten Empat Lawang Provinsi Sumatera Selatan.

\section{METODOLOGI PENELITIAN}

Penelitian ini dilaksanakan di SMA Negeri 2 Muara Pinang. Lokasi penelitian dapat dilihat pada gambar 1 peta lokasi penelitian. Metode penelitian pendidikan dapat diartikan sebagai cara ilmiah untuk mendapatkan data yang valid dengan tujuan dapat ditemukan, dikembangkan dan dibuktikan, suatu pengetahuan tertentu sehingga pada gilirannya dapat digunakan untuk memahami, memecahkan, dan mengantisifasi masalah dalam bidang pendidikan (Sugiono, 2015). Dalam penelitian ini metode penelitian yang digunakan adalah metode penelitian deskriptif.

Sumber data penelitian diperoleh dari siswa kelas X SMA Negeri 2 Muara Pinang yang berjumlah 30 siswa. Pemilihan sumber data ini dilakukan didasarkan pada kemamampuan berpikir spasial di kelas tersebut masih rendah. Kemudian, untuk mendapatkan data sekunder diperoleh dalam bentuk dokumen yang mendukung data penelitian ini.

Pengumpulan data penelitian ini berupa observasi, angket dan dokumentasi. Untuk mendapatkan data mengenai kemampuan berfikir spasial siswa dilakukan dengan memberikan angket kepada siswa agar dapat diketahui sejauh mana kemampuan berfikir spasial siswa. Selanjutnya, perolehan data yang telah terkumpul dilakukan analisis. Analisis yang digunakan dalam penelitian ini adalah analisis data secara persentase yang kemudian dikategorikan belum baik, cukup baik, baik dan sangat baik.

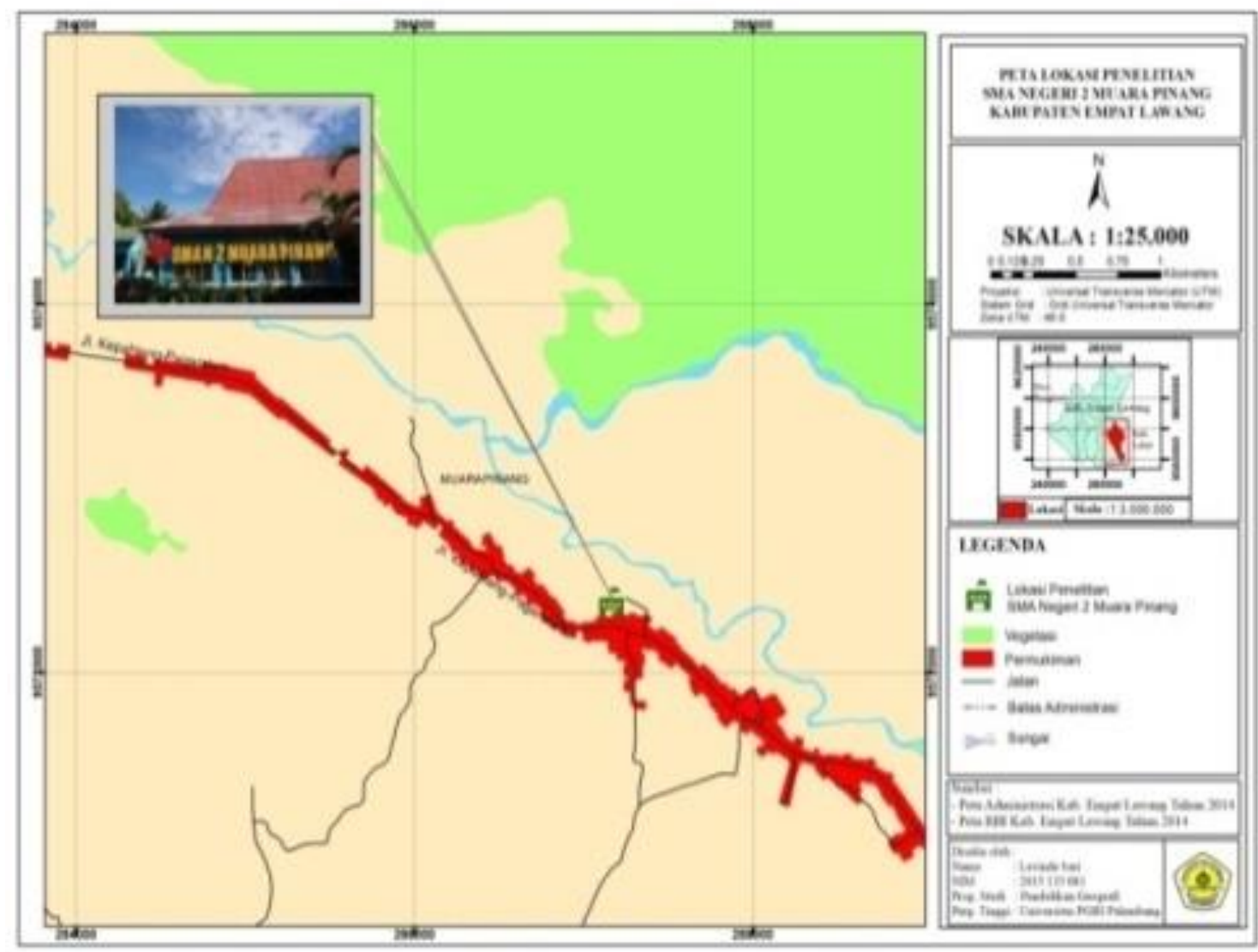

Gambar 1. Peta Lokasi Penelitian 


\section{HASIL DAN PEMBAHASAN}

Perolehan data mengenai kemampuan berfikir spasial siswa di kelas X SMA Negeri 2 Muara Pinang diperoleh melalui pembagian angket kepada siswa setelah dilaksanakan pembelajaran. Setelah data terkumpul selanjutnya data dianalisis secara persentase. Kemampuan berfikir spasial dalam penelitian ini disusun berdasarkan sejauh mana pemahaman siswa terhadap fenomena di sekitar wilayah siswa tinggal terutama pemahaman siswa terhadap lokasi. Pengenalan lokasi merupakan dasar dari kemampuan berpikir spasial (Oktavianto, Sumarmi, \& Handoyo, 2017).

Dilihat dari siswa menjawab pertanyaan tidak sesuai dengan fakta atau kebenaran yang ada. Dari analisis soal bagaimana jarak siswa ke sekolah sebagian besar 53\% menyatakan jauh lokasi sekolah mereka dari rumah dan dan $47 \%$ menyatakan tidak jauh rumah dengan lokasi sekolahnya. Hasil tersebut berdasarkan fakta lokasi sekolah jaraknya tidak jauh dari sekolah karena dinas pendidikan telah menetapkan sistem zonasi yang dimana lokasi sekolah tidak boleh jauh dari lokasi sekolah. Ini menunjukkan bahwa kemampuan spasial siswa dalam menjawab dapat dikatakan masih cukup baik.

Kemudian, hasil analisis topografi sekolah, siswa $10 \%$ menjawab daerah kawasan sekolah yaitu dataran tinggi dan sebagian besar siswa 56 $\%$ menjawab dataran rendah, sementara siswa yang menjawab tidak tau sebanyak $34 \%$. Jadi, kemampuan spasial siswa dalam menjawab topografi kawasan di sekolah disini cukup baik karena 56\% menjawab kawasan sekolah SMA Negeri 2 Muara Pinang merupakan kawasan dataran rendah. Sedangkan yang menjawab benar $10 \%$ karena kawasan di Sekolah tersebut berada di kawasan pegunungan dan perbukitan yang artinya merupakan kawasan dataran tinggi dan sebagian siswa lainnya menjawab tidak tahu. Siswa yang menjawab benar dalam pertanyaan ini $10 \%$ tetapi ketika ditanya mengapa memilih dataran tinggi mereka tidak tahu jawabannya.

Hasil analisis mengenai fenomena alam yang terjadi di sekirtar siswa, menjawab $14 \%$ siswa pernah mengalami fenomena alam dan sebagian besar $86 \%$ siswa menjawab tidak pernah mengalami fenomena alam di sekolah. Berdasarkan fakta lokasi SMA Negeri 2 ini berada tepatnya di kecamatan Muara Pinang kabupaten Empat Lawang dimana wilayah ini berdekatan kota bengkulu yang terdapat pantai, pantai terkenal salah satunya yaitu pantai Panjang. Kabupaten Empat Lawang yang berdekatan dengan kota Bengkulu merupakan salah satu daerah termasuk dalam jalur sirkum pegunungan mediterania karena itu, jika terjadi gempa kabupaten empat lawang akan merasakan getaran dari gempa tersebut dan sudah lebih dari satu kali terjadi. Dari hasil ini menunjukkan bahwa kemampuan spasial sangat rendah karena terdapat $14 \%$ siswa yang mengetahui hal tersebut.

Selain itu, jawaban siswa mengenai fenomena alam seperti banjir, terdapat $4 \%$ siswa menjawab rawan terjadi banjir dan sebagian besar siswa menjawab $96 \%$ tidak rawan terjadi banjir di lokasi sekolah. Berdasarkan fakta yang ada siswa menjawab 96\% tidak rawan banjir sudah benar karena lokasi sekolah tersebut masih dikelilingi hutan, kebun kopi, terdapat penghijauan dan berada di dataran tinggi bahkan masih terdapat rerumputan alami, maka dari jawaban tersebut kemampuan spasial siswa dalam menjawab pertanyaan sudah baik.

Selanjutnya, hasil analisis jawaban siswa $26 \%$ menjawab pernah terjadi gempa dan sebagian besar siswa $74 \%$ menjawab tidak pernah terjadi gempa di sekolah. Ini dapat dikatakan bahwa pengetahuan siswa terhadap fenomena yang terjadi di sekitar siswa masih rendah karena $74 \%$ siswa menjawab tidak pernah terjadi padahal sejak sekolah berdiri pada tahun 2011 hingga sekarang pernah terjadi gempa karena lokasi SMA Negeri 2 Muara Pinang atau lebih tepatnya daerah kecamatan Muara Pinang berdekatan dengan kota Bengkulu. Maka, dapat diketahui bahwa kemampuan spasial sebagian siswa masih rendah karena $26 \%$ siswa mengetahui fenomena tersebut selebihnya $74 \%$ siswa menjawab salah. Penelitian ini, tidak mengukur lamanya siswa tinggal bermukim sehingga ini perlu dilakukan uji lebih lanjut. 
Kemudian, hasil analisis siswa mengenai pengetahuan siswa dalam membaca peta terutama memahami legenda yang terdapat pada peta terdapat $96 \%$ siswa mengetahui simbol yang menjelaskan isi peta sisanya $4 \%$ siswa yang

di kabupaten Banyuasin dan seluruh siswa 100\% menjawab SMA Negeri 2 Muara Pinang terdapat di kabupaten Empat Lawang. Maka, dapat disimpulkan bahwa kemampuan berfikir spasial siswa dalam membaca peta dan lokasi administrative sekolah sudah sangat baik.

Pengetahuan siswa mengenai kondisi sekolah 96\% siswa mengetahui kondisi sekolah berdampak baik terhadap lingkungan sekitar dan siswa yang menjawab di kondisi sekolah berdampak buruk terhadap lingkungan sekitar yaitu hanya $4 \%$. Lalu, sebesar $60 \%$ siswa menjawab sekolah berdekatan dengan kepadatan penduduk sedangkan $40 \%$ siswa menjawab sekolah tidak berdekatan dengan kepadatan penduduk. Berdasarkan fakta yang ada lokasi sekolah berdampak baik terhadap lingkungan sekitar sudah sesuai fakta karena dengan adanya lokasi SMA Negeri 2 Muara masyarakat bisa menempuh pendidikan sesuai minatnya masingmasing dan sekolah tersebut jauh dari kepadatan penduduk apalagi sekolahnya pun baru di bangun dan jika kita melintasi pintu masuk dari baliho sampai ke lokasi sekolah hanya ada beberapa rumah warga saja di pinggir jalan dan sebagian besar masih terdapat hutan.

Lebih lanjut, hasil analisis mengenai pengetahuan siswa terhadap perbedaan sekolah SMA Negeri 2 Muara Pinang dengan Sekolah lain terdapat $20 \%$ siswa ada perbedaan lokasi yang sulit akses transportasi dan $20 \%$ ada perbedaan yaitu lokasi yang jauh dan $60 \%$ siswa menjawab tidak ada perbedaan lokasi sekolah dengan sekolah lainnya. Dilihat dari jawaban tersebut dimana sebanyak 20\% siswa memiliki kemampuan spasial yang masih rendah karena transportasi mudah di akses dan setelah sekolah SMAN 2 Muara Pinang banyak juga siswa yang bersekolah di SMPN 2 Muara Pinang melewati SMA Negeri 2 Muara Pinang sehingga mudah untuk menuju kesekolah, kemudian $20 \%$ siswa menjawab simbol lokasi sekolah yaitu permukiman dan yang menjawab vegetasi tidak ada. Lalu, pengetahuan siswa terhadap lokasi administrative sekolah, sebanyak $0 \%$ siswa menjawab SMA Negeri 2 Muara Pinang terdapat menjawab lokasi yang jauh sehingga kemampuan spasialnya juga belum baik karena di tahun 2019 telah dilaksanakannya zona sekolah dimana lokasi sekolah tidak boleh jauh dari rumah sekolah siswa dan sebagian besar kemampuan spasial siswa sudah cukup baik karena dapat diketahui sebagian besar sekolah secara fasilitas tidak ada perbedaan seperti di sekolah SMA Negeri 2 terdapat mushola, kantor guru dan ruang TU, toilet, kantin, lapangan basket, dll sama seperti sekolah lainnya.

Secara keseluruhan, dapat disimpulkan bahwa kemampuan spasial siswa cukup baik, meskipun masih ada siswa merespon belum sesuai fakta. Lalu, pengetahuan membaca peta terutama legenda serta mengetahui lokasi administrative sekolah sudah sangat baik. Sedangkan, kemampuan berfikir spasial siswa terhadap kondisi sekolah, perbedaan sekolah dengan sekolah lain belum cukup baik meskipun siswa mengetahui lokasi sekolah dengan lokasi sekolah lain sudah cukup baik. Kemampuan spasial tidak hanya terkait pada wilayah itu sendiri tetapi adanya ketekaitan dengan fenomena geografis. Studi tentang fenomena geografis tidak hanya menjelaskan adanya fenomena dan proses terjadinya fenomena di permukaan bumi tetapi juga bentuk, ukuran, arah, pola fenomena dan hubungannya dengan fenomena lainnya (Setiawan dalam Rahayu, Murjainah, \& Idris, 2019).

Penelitian ini menunjukkan bahwa pentingnya mempelajari spasial agar siswa dapat mengetahui dan memiliki kekampuan berfikir spasial. Ini sejalan dengan Lee (2009) yang menyatakan bahwa semua jenjang dalam sistem pendidikan seharusnya diajarkan tentang berpikir spasial.

\section{SIMPULAN}

Berdasarkan koesioner yang telah dibagikan kepada siswa kelas X SMA Negeri 2 Muara 
Pinang dapat menunjukkan bahwa kemampuan spasial siswa cukup baik, meskipun masih ada siswa merespon belum sesuai fakta. Hal ini dapat terlihat dari kemampuan siswa dalam menjawab soal tentang kemampuan untuk mengenali jarak, pola spasial sekolah, menganalisis fenomena alam, kemampuan mengetahui kondisi sekolah.

\section{DAFTAR PUSTAKA}

Hanafi. (2016). Studi Kemampuan Spasial Geografi Kelas Xll SMA Negeri 6 Kota Bengkulu, Universitas Prof Dr Hazairin Vol:3, No:2 Hal 14

Lee. (2009). Peran Sistem Informasi Geografis (SIG) Dalam Meningkatkan Kemampuan Berpikir Spasial (Spatial Thinking), Departemen Pendidikan Geografi, FPIPS, UPI:Vol 15

Musanna. (2017).

INDIGENISASI

PENDIDIKAN: Rasionalitas Revitalisasi Praksis Pendidikan Ki Hadjar Dewantara. Jurnal Pendidikan dan Kebudayaan, Vol. 2, Nomor 1, Juni 2017, 117-133.

NN, U. S., Murjainah, \& Tobari. (2018). Pengaruh Metode Pembelajaran Resitasi Berbasis Information Comunication Technology (ICT) Terhadap Hasil Belajar Geografi Siswa Kelas X di SMA Negeri 1 Palembang. Jurnal
Swarnabhumi Vol. 3, No. 2, Agustus 2018, 102-108.

Nofirman, N. (2018). Studi Kemampuan Spasial Geografi Siswa Kelas XII SMA Negeri 6 Kota Bengkulu. Jurnal Georaflesia VOL 3 NO 2, 11-24.

Okta, O., Murjainah, M., \& Edi , H. (2019). Aktivitas Belajar Siswa Pada Praktikum Penginderaan Jauh di SMA. Jurnal Geografi; Geografi dan Pengajarannya ISSN 1412 - 6982 Vol XVII No 2, 15-24.

Oktavianto, Sumarmi, \& Handoyo, B. (2017). Pengaruh Pembelajaran Berbasis Proyek Berbantuan Google Earth Terhadap Keterampilan Berpikir Spasial. Jurnal Teknodik Vol. 21 - Nomor 1, Juni 2017, 5969.

Rahayu, S., Murjainah, M., \& Idris, M. (2019). The Effect of Google Earth Utilization on Students' Spatial Thinking Ability. GEOSFERA INDONESIA p-ISSN 25989723, e-ISSN 2614-8528 Vol.4 No. 3 (2019), 291-301, December, 2019, 291-301.

Sugiyono. (2015). Metode Penelitian Kuantitatif kualitatif dan $R \& D$. Bandung: Alfabeta. 